\title{
Effect of Fermentation Time on the Proximate and Mineral Composition of Fermented African Oil Bean Seed 'Ugba'
}

\author{
Nwachukwu Chinaza Daniel ${ }^{1}$, Enyoh Emmanuel Chinedu', \\ Enyoh Christian Ebere ${ }^{2^{*}}$ and Amaobi Collins Emeka ${ }^{2}$ \\ 1 Department of Food Technology, School of Industrial and Applied Sciences, \\ Federal Polytechnic, Nekede, Owerri, Imo State, Nigeria \\ ${ }^{2}$ Group Research in Analytical Chemistry, Environment and Climate Change, \\ Department of Chemistry, Imo State University, Owerri, Imo State, Nigeria
}

*cenyoh@gmail.com

Keywords: Ugba, Mineral analysis, Fermentation, Quality, Food

\begin{abstract}
Ugba was produced by fermenting African oil bean seed samples for different periods of time. The Proximate and Mineral composition of fermented and unfermented African oil bean seed 'ugba' was investigated and the results showed that the Moisture content ranged from $49.32 \pm 0.08 \%$ to $51.32 \pm 0.06 \%$, the crude Fat content ranges from $17.80 \pm 0.08 \%$ to $19.36 \pm 0.12 \%$, the Protein content ranges from $15.46 \pm 0.05 \%$ to $17.36 \pm 0.07 \%$, the Ash content ranges from $1.94 \pm 0.03 \%$ to $2.64 \pm 0.00 \%$, the crude Fibre content ranges from $2.63 \pm 0.09 \%$ to $3.22 \pm 0.06 \%$ and the Carbohydrate content ranges from $6.33 \pm 0.01 \%$ to $12.15 \pm 0.07 \%$. The results from the mineral composition showed $\mathrm{Ca}$ from $86.35 \pm 0.09 \mathrm{mg} / 100 \mathrm{~g}$ to $92.11 \pm 0.09 \mathrm{mg} / 100 \mathrm{~g}$, $\mathrm{Mg}$ from $186.14 \pm 0.17 \mathrm{mg} / 100 \mathrm{~g}$ to $235.14 \pm 0.08 \mathrm{mg} / 100 \mathrm{~g}, \quad \mathrm{P}$ from $102.48 \pm 0.02 \mathrm{mg} / 100 \mathrm{~g}$ to $117.23 \pm 0.06 \mathrm{mg} / 100 \mathrm{~g}$ and $\mathrm{Fe}$ from $11.46 \pm 0.11 \mathrm{mg} / 100 \mathrm{~g}$ to $12.50 \pm 0.05 \mathrm{mg} / 100 \mathrm{~g}$. The results showed that the minerals and some of the proximate compositions increased as fermentation time increased, therefore giving an indication that fermentation improves the nutrient composition of Ugba.
\end{abstract}

\section{Introduction}

Fermentation is a metabolic process which involves the conversion of carbohydrate by microorganism into an alcohol or an acid. It is a simultaneous process which involves several catabolic and anabolic reactions that depends on several conditions, including substrate, micro flora, and environmental factors [1]. This metabolic conversion in food is owed greatly to microbial enzymic reactions [2]. Over the years, fermentation has become part of the culture and traditions of most indigenous communities in developing countries especially in Africa [3]. Nigeria as well as other countries in Africa depend on this foods to satisfy their nutritional needs [1].

'Ugba' is a value added solid substrate fermentation product of African Oil bean (Pentaclethra macrophylla Benth) seed prepared by the Ibos in Eastern Nigeria [4]. African oil bean seed which is rich in essential amino acids as well as fatty acids and minerals (Calcium, Magnesium and Phosphorous) has been found to be a highly nutritive animal feed when fortified [5]. The seed contains more than $52 \%$ oil in its cotyledons [6], with polyunsaturated fatty acid especially Linoleic and Oleic acids constituting more than $82 \%$ of the fatty acids in the seed [7]. For this reason, Ugba a cheap protein source and well as its high nutritive capacity is widely consumed as a snack, side dish or food condiment in most developing countries [4].

Several reports on the production of fermented condiments have been recorded. [3] studied the effect of varying fermentation temperature on proximate composition and mineral content of african oil bean seeds (Pentaclethra macrophylla Benth). Result revealed that there was a decrease in the mineral nutrient of the fermented oil been seed as time increases. [19] in his research on the evaluation of the nutritional potentials of fermented oil beans seed (Pentaclethra macrophyllah Benth), revealed result indicating an increase in the mineral composition as the number of days of fermentation increases. Studies from African locust bean 'iru' [8], melon seed, fermented Ogi [9] 
and soybean 'Daddawa' [10] have also been conducted. Result revealed that the chemical composition of these condiments could contribute to the daily intake of proteins, lipids and minerals when used liberally, as practiced in several homes, where expensive animal products are a luxury [10]. Traditionally fermented oil bean seed may not have a significant effect on the lipid composition of the seed but might greatly affect its protein composition though still maintaining at least $55 \%$ of its nutritional value [18].

The nutritional composition of Ugba may vary due soil profile, geography and climate conditions. In the present study, we evaluated the effect of fermentation time on the proximate and mineral composition of fermented oil bean seed 'ugba' sold in different markets in Nigeria. The scope of this work includes; (a) varying the fermentation time in the production of 'ugba' (b) Proximate analysis of fermented oil bean seed 'ugba' (c) Mineral analysis of fermented oil bean seed which includes; Calcium, Magnesium, Phosphorous and Iron determination. This research will help to improve the method of processing African oil bean seed into ugba and therefore help to standardize the quality of ugba sold in different markets in Nigeria.

\section{Materials and Methods}

\section{Raw material procurement}

The African oil bean seeds used for this research were purchased from Apumiri Market in Ubakala, Umuahia South L.G.A, Abia State. The Chemicals/reagents and equipments used in carrying out this research were gotten from the laboratory of Federal Polytechnic, Nekede in owerri where this research was carried out. The chemicals used were of analytical grade and includes Hydroxilamine hydrochloride, Sodium cyanide and Potassium ferrocyanide, diethyl ether, sulphonic acid, sodium hydroxide, alcohol, distilled water, methyl red indicator, boric acid, hydrochloric acid, ammonia buffer, erichrome dark $\mathrm{T}$. indicator, orthophenathroline solution, hydroxylamine hydrochloride, ammonium molybdate solution, ascorbic acid solution.

\section{Production of ugba from African oil bean seed}

The ugba was produced according to the methods of [13]. $1 \mathrm{~kg}$ of African oil bean seed which was purchased from the market was manually sorted and washed in order to remove the spoilt seeds, dust and extraneous matter from the seed.

The already sorted and cleaned oil bean seeds were placed in an aluminum pot, covered with water and boiled for 45 minutes after which it was drained and left to cool before the seeds were dehulled and sliced with a knife. The sliced seeds was then placed in an aluminum pot with water covering the shreds in the pot and it was then boiled for the second time for 30minutes, after the second boiling the shreds were allowed to cool before it was drained and washed three times with a clean cold water after which it was steeped for 10hours before it was drained washed with cold water again, drained and packaged with a plantain leave and allowed to ferment.

\section{Proximate Analysis of African Oil Bean Seed}

\section{Moisture content determination}

The AOAC [11] method no. 945.38 was used. $5 \mathrm{~g}$ of the sample were weighed into clean, dried and pre-weighed crucibles. The crucibles and their contents were dried in the moisture extraction oven at $110^{\circ} \mathrm{C}$ for 4 hours. The samples were then removed from the oven, cooled in a desiccator and reweighed. The samples were again put back into the oven and dried until a constant weight was obtained. This analysis was carried out in triplicate and the average value was recorded as moisture content.

$$
\% \text { Moisture }=\frac{\text { Initial weight of sample-weight of oven dried sample }}{\text { initial weight of sample }} \times 100
$$




\section{Crude fat determination}

Method no. 920.39A was used [11]. 5g of the air dried ground sample was weighed into a filter paper, wrapped carefully and put in the sample holder of the soxhlet extraction apparatus. A clean dried and weighed soxhlet extraction flask was half filled with diethyl ether and the whole apparatus was assembled together, and the flask placed on the heating mantle and heated at $34^{0} \mathrm{C}$. The fat was extracted for three hours. Then, the sample holder was disconnected and the extraction flask removed. At the end of 3 hours (end of extraction) the sample holder was disconnected and the sample removed. Then, the equipment was reassembled with only the extraction flask and its oil content. The flask was then heated at $34^{\circ} \mathrm{C}$ and the solvent evaporated leaving the oil in the flask. The oil was dried in a moisture extraction oven in order to remove the solvent residues in oil. The dried sample was cooled in a dessicator and reweighed. The drying, cooling and reweighing of the oil sample were repeated until a constant weight was obtained. The percentage fat contained was determined thus:

$$
\% \text { Crude fat }=\frac{\text { weight of flask }+ \text { oil-weight of empty flask }}{\text { initial weight of sample }} \times 100
$$

\section{Crude fibre determination}

Method No. 942.05 (AOAC) was used [11]. 2g of defatted sample was weighed into $250 \mathrm{ml}$ beaker containing $200 \mathrm{ml}$ of $0.125 \mathrm{M}$ tetraoxosulphate iv acid (Sulphuric acid). The mixture was heated in a steam bath at $70^{\circ} \mathrm{C}-90^{\circ} \mathrm{C}$ for 2 hours, and then allowed to cool. The cooled mixture was filtered using a muslin cloth over a Buckner funnel. The residue was washed three times with hot water to remove the acid and then put in a beaker containing $200 \mathrm{ml}$ of sodium hydroxide. The mixture was heated as before over a steam bath for 2 hours. The solution was filtered and the residue washed three times with hot water, then with alcohol and water.

The final residue obtained was put in clean pre-weighed crucible and dried at $120^{\circ} \mathrm{C}$ to a constant weight. The crucible with the oven dried sample as put in a muffle furnace and ashed at $550^{\circ} \mathrm{C}$ for 30 minutes such that the sample became ash white. The crucible and its contents were removed from the furnace, cooled in a dessicator and reweighed. Percentage fibre was calculated as followed:

$$
\% \text { Crude fibre }=\frac{\text { weight of dried sample-weight of ash }}{\text { initial weight of sample }} \times 100 .
$$

The analysis was done in triplicate and the average taken as percentage crude fibre.

\section{Crude protein determination}

Method no. 955.04C called the Kjeldahl method was used [11]. This method was divided into three namely, digestion, distillation and titration.

Digestion: Approximately $0.2 \mathrm{~g}$ of ground air dried African oil bean seed sample was weighed into clean dried Kjeldahl flask for digestion, and $0.1 \mathrm{~g}$ copper tetraoxosulphate iv crystals, $0.5 \mathrm{~g}$ sodium tetraoxosulphate iv crystal and $25 \mathrm{ml}$ of concentrated $\mathrm{H}_{2} \mathrm{SO}_{4}$ acid were added into the flask and some glass beads were added into the flask content as anti-bumping agents. The Kjeldahl flask and its content were transferred to the digesting chamber in a fume cupboard and digested. Digestion continued with constant rotation of the digestion flask until the sample changed colour (that is from black to light blue). The digestion flask was then removed from the digesting chamber and allowed to cool. The digest was made up to $100 \mathrm{ml}$ using distilled water and shaken vigorously to a homogenous solution.

Distillation: Out of the homogenous solution of the digest, $20 \mathrm{ml}$ was transferred into a distillation flask using a pipette. Then $20 \mathrm{ml}$ of $40 \%$ sodium hydroxide solution was added carefully down the side of the flask through a funnel. Then $50 \mathrm{ml}$ of $2 \%$ boric acid solution was pipetted into a receiving flask and two drops of methyl red indicator added. The distillation unit was fitted such that the condenser was connected to the receiving flask with a glass tube, and the condenser cooled 
with constant supply of cold water from tap. Also, the tip of the glass tube was immersed in the boric acid. The distillation unit was then heated on a heating mantle until the pink solution of the boric acid turned blue and the volume increased to about $100 \mathrm{ml}$ by the distillate.

Titration: Ten millilitres of the distillate was titrated against $0.1 \mathrm{~N}$ hydrochloric acid to a colourless end point. A blank solution was also titrated to get any trace of nitrogen in the blank. All the titre volumes were recorded. The percentage crude protein was calculated as follows:

$$
\% \text { Crude protein }=\% \text { Nitrogen } \mathrm{X} 6.25
$$

where

$$
\% \text { Nitrogen }=\frac{28}{100} x \frac{V_{t}-V_{b}}{W_{0}},
$$

$\mathrm{Vt}=$ titre volume of sample, $\mathrm{Vb}=$ titre volume of blank, $\mathrm{Wo}_{\mathrm{o}}=$ weight of sample.

\section{Ash content determination}

The AOAC (1990) method No 942.05 was used [11]. Clean dried crucibles were weighed on an electronic balance and $5 \mathrm{~g}$ of sample weighed into the crucibles. The samples were dried in the moisture extraction oven until constant weights were obtained. Then, the samples were transferred into the muffle furnace with a pair of tongs and ashed at $550^{\circ} \mathrm{C}$ for 4 hours until a white ash was obtained. The sample were removed from the furnace and cooled in a desiccator, and reweighed. The percentage ash was calculated as followed and the average taken:

$$
\% \text { Ash Conten }=\frac{\text { weight of ash }}{\text { initial weight of sample }} \times 100
$$

\section{Carbohydrate content determination}

The carbohydrate content of the sample was obtained by difference, that is, as the difference between the total summations of percentage moisture, fat, fibre, protein, Ash and 100

$$
\% \text { Carbohydrate }=100-(\% \text { moisture }+\% \text { fat }+\% \text { protein }+\% \text { fibre }+\% \text { ash }) .
$$

\section{Mineral analysis of ugba produced from African oil bean seed}

Mineral content of the sample was done following the dry ash extraction method [12]. A measured weight of the sample was burnt to ashes (as in ash determination), removing all the organic materials leaving only the inorganic ash. The resulting ash was dissolved in $5 \mathrm{mls}$ of diluted (2M) $\mathrm{HCl}$ solution and then diluted to $100 \mathrm{mls}$ in a volumetric flask. This was used in specific analysis for different mineral elements.

\section{Determination of calcium and magnesium}

Calcium and Magnesium content of the samples were determined by complexiometric titration. The verdanate EDTA titrimetric method of (AOAC, 2005) was employed. 20 mls portion of the sample was dispersed into a conical flask and treated with pinches of masking agents (Hydroxilamine hydrochloride, Sodium cyanide and Potassium ferrocyanide). The flask was added to it to raise the $\mathrm{pH}$ to 10.00 (a point at which both Calcium and magnesium form complexes with EDTA). The mixture was titrated against $0.02 \mathrm{~N}$ EDTA solution using Erichrome dark $\mathrm{T}$ as indicator. A reagent blank was titrated and titration in each case was done from deep red to a permanent blue end point. The titration values represent both $\mathrm{Ca}^{2+}$ and $\mathrm{Mg}^{2+}$ in the test sample. A reagent titration was done to determine calcium alone in the test samples.

Titration of Calcium alone was done similarly with the above titration. However, $10 \% \mathrm{NaOH}$ was used in place of Ammonia buffer and Solochrome dark blue indicator in place of Erichrome dark T. From the titre values obtained, the $\mathrm{Ca}^{2+}$ and $\mathrm{Mg}^{2+}$ content was calculated as follows;

$$
\text { Ca or } \mathrm{Mg}(\mathrm{mg} / 100 \mathrm{~g})=\frac{100 \times T-B(N \times \text { Ca or Mg }) \times V_{t}}{W \times V_{a}}
$$


where $\mathrm{W}=$ Weight of sample, $\mathrm{T}=$ Titre value of sample, $\mathrm{B}=$ Titre value of blank, $\mathrm{Ca}=\mathrm{Calcium}$ equivalence, $\mathrm{Mg}=$ Magnesium equivalence, $\mathrm{N}=$ Normality of titrate (0.02N EDTA).

\section{Determination of iron-orthophenatroline method}

$10 \mathrm{~cm}^{3}$ of the sample extract was pipetted into a $50 \mathrm{~cm}^{3}$ volumetric flask and $2 \mathrm{~cm}^{3}$ of $10 \%$ hydroxylamine hydrochloride solution was added into the flask. $20 \mathrm{~cm}^{3}$ of $10 \%$ sodium citrate solution and $2 \mathrm{~cm}^{3}$ of $0.25 \%$ orthophenathroline solution was then added into the flask and a distilled water was added into the flask to make it up to $50 \mathrm{~cm}^{3}$ and it was allowed to stay for 24 hours before the iron content was determined using a spectrophotometer with the blank set at zero to take the absorbance or reading of the sample at $510 \mathrm{~nm}$.

\section{Determination of phosphorus content using ascorbic acid method}

$1 \mathrm{~cm}^{3}$ of the plant extract was pipetted into a tall test tube and $1 \mathrm{~cm}^{3}$ of $2.5 \%$ Ammonium Molybdate solution and $1 \mathrm{~cm}^{3}$ of $20 \%$ Ascorbic acid solution was also added to it and mixed very well, the volume was then made up to $10 \mathrm{~cm}^{3}$ with distilled water. The mixture was then heated with boiling water bath for about five minutes for the blue color to develop. After the heating, it was cooled and the reading or absorbance was taken at $882 \mathrm{~nm}$ using a spectrophotometer with a blank set at zero.

\section{Data analysis}

T-test statistics were used to test for significant differences between means at $5 \%$ significance level. The analysis was done using Microsoft Excel 2010.

\section{Results and Discussion}

Table 1 shows the result of proximate composition of fermented and unfermented African oil bean seed 'Ugba'. From the results, the moisture content values ranges from $49.32 \pm 0.08 \%$ to $51.32 \pm 0.06 \%$, the unfermented sample has the lowest value while the sample which was fermented for 72 hrs ( 3 days) has the highest value, these values were slightly higher compared to the value reported by [14] which was $46.80 \%$. However, [13] who worked on African oil bean seed which was fermented for $72 \mathrm{hrs}$ (3 days) reported a higher moisture content of $95.00 \%$. However, [17] reported a moisture value of $51.88 \%$ for a sample which was fermented for five days.

The crude fat values ranges from $17.80 \pm 0.08 \%$ to $19.36 \pm 0.12 \%$, the unfermented Sample gave the lowest value while the sample which was fermented for $72 \mathrm{hrs}$. (3 days) gave the highest value. However, these values were very small compared to the $53.98 \%$ which was reported by [16] for a sample which was fermented for 72 hrs (3 days). Also, [13] who worked on a sample which was fermented for $72 \mathrm{hrs}$ reported a higher fat value of $35.00 \%$, his result was slightly different from that of [17] who reported $37.36 \%$ for a sample which was fermented for five days.

The unfermented sample again had the lowest crude protein value of $15.46 \pm 0.05 \%$ while the sample which was fermented for $72 \mathrm{hrs}$ had the highest value of $17.63 \pm 0.07 \%$. These values were very low compared to the ones found in literature, [16] reported $22.32 \%$ for a sample which was fermented for $72 \mathrm{hrs}$ while [17] reported a value of $23.02 \%$, for a sample which was fermented for five day, however, these values from literature gained more support from the work of [13] who reported $31.95 \%$ for a sample which was fermented for $72 \mathrm{hrs}$.

The Ash content values ranges from $1.94 \pm 0.03 \%$ to $2.64 \pm 0.00 \%$, the unfermented sample has the lowest value while the sample which was fermented for $48 \mathrm{hrs}$ ( 2 days) has the highest value. However, [11] reported $1.08 \%$ for a sample which was fermented for 72 hrs while [16] reported a value of $2.40 \%$ for a sample which was fermented for $72 \mathrm{hrs}$ but [17] reported the lowest value of $0.24 \%$ for a sample which was fermented for five days.

The crude fibre values ranges from $2.69 \pm 0.09 \%$ to $3.22 \pm 0.06 \%$ with the unfermented sample giving the highest value while the sample which was fermented for 72 hours ( 3 days) had the lowest value. [13] reported $2.60 \%$ for a sample which was also fermented for $72 \mathrm{hrs}$ as reported in this 
work. However, [17] also reported the same value for a sample which was fermented for five days while [16] reported $2.13 \%$ for a sample which was fermented for 72 hours (3 days) also.

Table 1. Proximate composition of Ugba produced from African oil bean (Pentaclethra macrophylla Benth) seed

\begin{tabular}{lllll}
\hline COMPONENTS & \multicolumn{3}{c}{ Unfermented } & \multicolumn{3}{c}{ Fermented } \\
\cline { 3 - 5 } & & $\mathbf{2 4} \mathbf{~ h r s}$ & $\mathbf{4 8} \mathbf{~ h r s}$ & $\mathbf{7 2 ~ h r s}$ \\
\hline Moisture & $49.32^{\mathrm{a}}$ & $49.56^{\mathrm{a}}$ & $50.90^{\mathrm{b}}$ & $51.32^{\mathrm{c}}$ \\
Crude fat & $17.80^{\mathrm{a}}$ & $18.17^{\mathrm{b}}$ & $18.85^{\mathrm{c}}$ & $19.36^{\mathrm{d}}$ \\
Crude protein & $15.46^{\mathrm{a}}$ & $15.91^{\mathrm{b}}$ & $16.88^{\mathrm{c}}$ & $17.63^{\mathrm{d}}$ \\
Ash & $1.94^{\mathrm{a}}$ & $2.45^{\mathrm{b}}$ & $2.64^{\mathrm{d}}$ & $2.62^{\mathrm{c}}$ \\
Crude fibre & $3.22^{\mathrm{d}}$ & $3.05^{\mathrm{c}}$ & $2.85^{\mathrm{b}}$ & $2.69^{\mathrm{a}}$ \\
Carbohydrate & $12.15^{\mathrm{d}}$ & $10.84^{\mathrm{c}}$ & $7.87^{\mathrm{b}}$ & $6.33^{\mathrm{a}}$ \\
\hline
\end{tabular}

Means within the same column with the same superscript are not significantly different at $5 \%$ level $(\mathrm{p}<0.05)$.

The carbohydrate values ranges from $12.15 \pm 0.07 \%$ to $6.33 \pm 0.01 \%$, with the unfermented sample giving the highest value while the sample which was fermented for 72 hours ( 3 days) has the lowest value. From the results, it was observed that almost all the components increased in value as the fermentation time increase. More so, some of the values from the results competed favorably with the ones found in literature while some did not.

The differences in values of the proximate composition may be due to dryness of the seed (whether freshly harvested-high moisture content or Dried and stored-low moisture content), degree of maturity (higher fat and protein contents for matured seeds) [14].

Table 2 shows the result of the mineral composition of fermented and unfermented African oil bean seed 'Ugba'. From the results, the values for Calcium composition ranges from $86.35 \pm 0.09 \mathrm{mg} / 100 \mathrm{~g}$ to $92.11 \pm 0.09 \mathrm{mg} / 100 \mathrm{~g}$, the unfermented sample has the lowest value while the sample which was fermented for $72 \mathrm{hrs}$ has the highest value. However, these values were very low compared to the one reported by [16] which was $314.28 \mathrm{mg} / 100 \mathrm{~g}$ for a sample which was fermented for $72 \mathrm{hrs}$ while [15] reported a higher value which was $329.59 \mathrm{mg} / 100 \mathrm{~g}$.

The Magnesium values ranges from $186.14 \pm 0.17 \mathrm{mg} / 100 \mathrm{~g}$ to $235.14 \pm 0.08 \mathrm{mg} / 100 \mathrm{~g}$, the unfermented sample has the lowest value while the sample which was fermented for $72 \mathrm{hrs}$ has the highest value. However, the value from the sample which was fermented for $72 \mathrm{hrs}$ was comparable with the value reported by [16] which was $292.05 \mathrm{mg} / 100 \mathrm{~g}$, [15] reported a value of $292.90 \mathrm{mg} / 100 \mathrm{~g}$ although he did not state how long he fermented the sample.

The values for Phosphorous ranges from $102.48 \pm 0.02 \mathrm{mg} / 100 \mathrm{~g}$ to $117.23 \pm 0.06 \mathrm{mg} / 100 \mathrm{~g}$, the unfermented sample has the lowest value while the sample which was fermented for $72 \mathrm{hrs}$ has the highest value. These values were lower compared to the one reported by [16] which was $351.89 \mathrm{mg} / 100 \mathrm{~g}$ for a sample which was fermented for $72 \mathrm{hrs}$. However, the values in this work were very high compared to the $4.9 \mathrm{mg} / 100 \mathrm{~g}$ which was reported by [15] although he did not state how long the sample was fermented.

Table 2. Mineral composition of ugba produced from African oil bean (Pentaclethra macrophylla Benth) seed

\begin{tabular}{|c|c|c|c|c|}
\hline \multirow[t]{2}{*}{ COMPONENTS } & \multirow{2}{*}{$\begin{array}{l}\text { Unfermented } \\
\mathrm{mg} / 100 \mathrm{~g}\end{array}$} & \multicolumn{3}{|c|}{ Fermented } \\
\hline & & $\begin{array}{l}24 \mathrm{hrs} \\
\mathrm{mg} / 100 \mathrm{~g}\end{array}$ & $\begin{array}{l}48 \mathrm{hrs} \\
\mathrm{mg} / 100 \mathrm{~g}\end{array}$ & $\begin{array}{l}72 \mathrm{hrs} \\
\mathrm{mg} / 100 \mathrm{~g}\end{array}$ \\
\hline Calcium & $86.35^{\mathrm{a}}$ & $87.34^{\mathrm{b}}$ & $89.58^{c}$ & $92.11^{\mathrm{d}}$ \\
\hline Magnesium & $186.14^{\mathrm{a}}$ & $221.53^{b}$ & $226.19^{c}$ & $235.14^{c}$ \\
\hline Phosphorus & $102.48^{\mathrm{a}}$ & $105.16^{\mathrm{b}}$ & $110.34^{\mathrm{c}}$ & $117.23^{\mathrm{d}}$ \\
\hline Iron & $11.40^{\mathrm{a}}$ & $11.74^{\mathrm{b}}$ & $12.50^{\mathrm{c}}$ & $11.62^{b}$ \\
\hline
\end{tabular}

Means within the same column with the same superscript are not significantly different at $5 \%$ level $(\mathrm{p}<0.05)$ 
The value for Iron composition ranges from $11.40 \pm 0.11 \mathrm{mg} / 100 \mathrm{~g}$ to $12.50 \pm 05 \mathrm{mg} / 100 \mathrm{~g}$, the unfermented sample has the lowest value while the sample which fermented for 48 hrs has the highest value, however, these were very low compared to the values reported by [16] which was $56.28 \mathrm{mg} / 100 \mathrm{~g}$ for a sample which was fermented for $72 \mathrm{hrs}$, Okwuonu et al. [15] also reported a higher value of $140.97 \mathrm{mg} / 100 \mathrm{~g}$ although he did not state how long the sample was fermented.

From the results in the table, it can be observed that the mineral compositions also increased as the fermentation time increased. However, the differences in values from the results of this work and those found in literature may have occurred as a result of variation in maturity, dryness, processing methods and the microorganisms involved in the fermentation of the seed.

\section{Conclusion and Recommendations}

This study on the effect of fermentation on the Proximate and Mineral composition of fermented African oil bean seed showed that fermentation does not only remove the anti-nutrients in Ugba but also add value to it by increasing its nutritional composition since the Proximate and Mineral composition of the product increased as the time of fermentation increased. However, this increases its moisture content thereby making it vulnerable to spoilage. It is recommend that this product "Ugba" be fermented for up to three days before consumption since fermentation adds value to it, but more research should be done to develop a best way to preserve it so as to ferment it more since fermentation improves its nutrient composition but makes it vulnerable to spoilage by increasing its moisture content. Also, efforts should be made to industrialize its production so as to encourage its export.

\section{Conflict of Interest}

The authors declare that there is no conflict of interest.

\section{References}

[1] S.K. Sathe, N.R. Reddy, M.D. Pierson, Future of legume fermented foods, in: N.R. Reddy, M.D. Pierson, D.K .Salunkhe (Eds.), Legume-based Fermented Foods, CRC Press Inc. USA, 1986, pp 233-235.

[2] C.O.O. Kabuo, Solar preservation of 'Ugba', a fermented product of African Oil bean seed (Pentaclethra macrophylla); effect on proximate composition, shelf life and organoleptic quality, in: Proceedings of the NIFST 25th Annual Conference, 5-9th November, Lagos, 2001, pp. 261-262.

[3] E.C. Okechukwu, A.Y. Itah, S.O. Aguora, Effect of varying fermentation temperature on proximate composition and mineral content of African oil bean seeds (Pentaclethra macrophylla Benth), Journal of Environmental Science, Toxicology and Food Technology. 6 (2015) 21-25.

[4] T.N.T. Nwagu et al., Mixed microbial flora as starter culture for the production of ugba from oil bean seed, Journal of Biological Science. 30 (2011) 1996-1998.

[5] E.C. Egonu, U. Njoku, Production and shelf-life studies of African oil bean peanut butter, Nigerian Journal of Microbiology. 20(2) (2006) 987-993.

[6] V.N. Enujiugha, Nutrient changes during the fermentation of African oil bean (Pentaclethra macrophylla Benth) seeds, Pakistan Journal of Nutrition. 2(5) (2003) 320-323.

[7] V.N. Enujiugha, O. Ayodele-Oni, Evaluation of nutrients and some anti-nutrients in lesserknown, underutilized oilseeds, International Journal of Food Science and Technology. 38(5) (2003) 525-528. 
[8] O.U. Eka, Effect of fermentation on the nutritional status of locust beans, Food Chem. 5(4) (1980) 305-348.

[9] S.A. Odunfa, Microorganisms associated with fermentation of African locust beans (Parkia filicoidea) during iru preparation, J. Plant Foods. 3(4) (1981) 245-250.

[10] B.O. Omafuvbe, O.O. Shonukan, S.H. Abiose, Microbiology and biochemical changes in the traditional fermentation of soybeans for 'soy-daddawa'-Nigerian food condiments, Food Microbiol. 17(5) (2000) 469-474.

[11] Association of Official Analytical Chemists, AOAC, Official Methods of Analysis, 15 edition, Arlington Virginia, U.S.A., 1990, pp. 951-959.

[12] C.S. James, Analytical chemistry of foods, Chapman and Hall, New York, 1995.

[13] B.I. Balogun, Evaluation of the nutritional potentials of fermented oil bean seed (Pentaclethra macrophylla Benth) production, Agriculture and Technology Journal. 9(2) (2013) 73-87.

[14] M.D. Pierson, N.R. Reddy, S.A. Odunfa, Other legume-based fermented foods, in: N.R. Reddy, M.D. Pierson, D.K., Salunkhe (Eds.), Legume-Based Fermented Foods, CRC Press, New York, 1986, pp. 219-222.

[15] G.C. Okwuonu et al., Case Report The potential anti hypertensive effects of the African oilbean seed - Pentaclethra Macrophylla Bentham, Pioneer Medical Journal. 3(5) (2013) 111.

[16] V.N. Enujiugha, C.T. Akanbi, Composition changes in African oil bean (Pentaclethra macrophylla Benth) seed during thermal processing, Pakistan Journal of Nutrition. 4(1) (2005) 27-31.

[17] R.I. Okechukwu et al., Changes in nutrient composition of African oil bean meal "ugba" (Pentaclethra macrophylla Benth) subjected to solid state natural fermentation, Journal of Applied Bioscience. 51 (2012) 3591-3595.

[18] S.C. Achinewhu, Protein quality of African oil bean seeds (Pentaclethra macrophylla Benth), Journal of Food Science. 48 (1983) 1374-1375.

[19] B.I. Balogun, Evaluation of the nutritional potentials of fermented oil beans seed Pentaclethra macrophyllah Benth, PAT. 9(2) (2013) 73-87. 